\title{
The Effects of Student Motivation and Self-regulated Learning Strategies on Student's Perceived E-learning Outcomes and Satisfaction
}

\author{
Sean Eom \\ Southeast Missouri State University
}

Structural equation modeling is applied to examine the effects of intrinsic motivation, extrinsic motivation, and self-regulated learning strategies on e-learners' satisfaction and their perceived learning outcomes. A total of 372 valid unduplicated responses from students who have completed at least one online course at a university in the Midwest were used to examine the structural model. The results indicated that intrinsic motivation, self-regulated learning strategies affect e-learners' learning outcomes. However, extrinsic student motivation had no significant relationship with learning outcomes. Nevertheless, it affected the self-regulated learning. The findings suggest that intrinsic motivation was the strongest predictors of e-learning outcomes.

Keywords: Distance Education/Distance Learning, Intrinsic Motivation, Extrinsic Motivation, SelfRegulated Learning Strategies, Perceived Learning Outcomes, Perceived Student Satisfaction

\section{INTRODUCTION}

One of well-known learning effectiveness model is the virtual learning environment (VLE) effectiveness model (Piccoli, Ahmad, \& Ives, 2001), which postulated that two antecedents (human dimension and design dimension) determine effectiveness of e-learning systems. The human dimension is concerned with two human entities (students and instructor) and their various attributes, and the design dimension includes learning management systems (LMS), self-regulated learning and learner control, course design, and interaction among e-learning entities.

The VLE effectiveness model is further extended to a comprehensive model \{Eom, 2018 \#26915\}. The essence of the new e-learning success model are dialogue, student self-regulation, and psychological and cognitive learning processes taking place in students' mind (see figure1). The students' learning/cognitive process is affected by multiple dimensions of learners' characteristics including biological characteristics/senses (physiological dimension); personality characteristics such as attention, emotion, motivation, and curiosity (affective dimension); information processing styles such as logical analysis, or "gut" feelings (cognitive dimension); and psychological/individual differences (psychological dimension) (Dunn, Beaudry, \& Klavas, 1989).

The primary objective of this study is to empirically investigate the effects of motivation and selfregulated learning strategies on students' perceived learning outcomes and satisfaction in university online education. Several attributes of students, as the primary participants of e-learning systems, have been major subjects of intense research over the past decade (S. B. Eom \& Arbaugh, 2011). Prior research findings identified a set of 31 determinants that have a significant effect on satisfaction and learning 
outcomes (Bitzer \& Janson, 2014). Their findings include several attributes of learners such as prior experience with learning management systems (LMS), computer experience, self-efficacy, learning styles, motivation, metacognition, and learning engagement. The next section introduces a system's view of elearning that includes the review of the literature on the effects of motivation and self-regulated learning strategies on e-learners' learning outcomes and satisfaction. We follow this with a description of the cross-sectional survey that was used to collect data and the results from a Partial Least Squares (PLS) analysis of the research model. The final section summarizes important findings and discusses the implications of the results for the e-learning area.

\section{A SYSTEM'S VIEW OF E-LEARNING}

A system's view of e-learning success model is a new theoretical model (S. B. Eom \& Ashill, 2018). It presents a learning theory-based integrated and comprehensive e-learning success model. Two previous studies (S. B. Eom \& Ashill, 2016; S. B. Eom et al., 2006) found no direct significant relationships between students' self-regulated learning behavior and perceived learning outcomes. The system's view of e-learning helps us view and analyze e-learning systems as a dynamic set of interdependent sub-entities interacting together. The components of a systemic model consist of inputs, processes, and outputs (Figure 1).

\section{Inputs}

The left side of Figure 1 shows three inputs to the learning system: Students, the instructor, learning management systems and information systems. theoretical foundation of this research model is based on the constructivist learning theories as discussed in Eom \& Ashill (2016). This model is in part derived from the virtual learning environment (VLE) effectiveness model of Piccoli et al. (2001). The VLE model postulates that two antecedents (human dimension and design dimension) determine the effectiveness of e-learning systems. The human dimension is concerned with two human entities (students and instructor) and their various attributes(S. B. Eom, 2006; Sean B. Eom, 2015). Another inputs to e-learning systems are learning management systems (S. B. Eom, 2014) and information technology. The quality matters (QM) rubric standards are a set of general standards and specific review standards include course technology. The course technology refers to a variety of information technology to be used in the online/blended course to support the learning objectives and to promote learner engagement and active learning (S. Eom, 2019; S. B. Eom, Ashill, Arbaugh, \& Stapleton, 2012).

\section{Processes}

The system's view of e-learning success is built on the fundamentally different conceptual framework that says learning outcomes and learner satisfaction are system's outputs. Figure 1 depicts three distinct types of process that produce learning outcomes and satisfaction: the learning and cognitive process, student self-regulation, and dialogue (S. B. Eom \& Ashill, 2016, 2018).

\section{The Students' Self-regulated Learning Process}

According to Zimmerman, self-regulated students are the ones who are "'meta-cognitively,' motivationally, and behaviorally active participants in their own learning process" (B.J. Zimmerman, 1986) and they are characterized by three inseparable features: their use of self-regulated learning strategies, their responsiveness to self-oriented feedback about learning effectiveness, and their interdependent motivational processes (Barry J. Zimmerman, 1990). The selection and use of specific self-regulated learning strategies and its effects on learning outcomes have been on-going research in the e-learning area(S. B. Eom, 2012; Sean B. Eom, 2015; S. B. Eom, 2017). 
FIGURE 1

SYSTEM'S VIEW OF E-LEARNING SYSTEMS

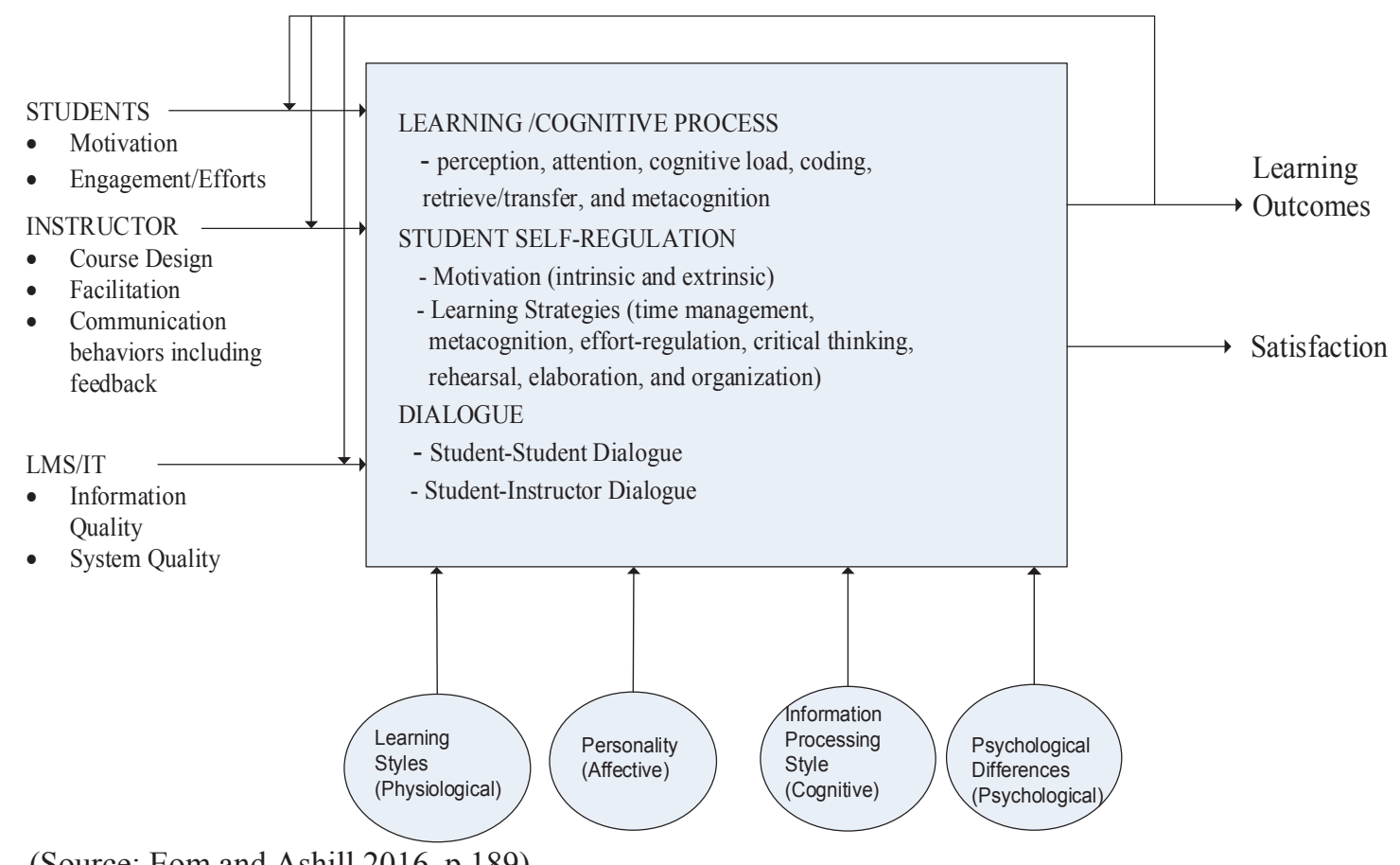

(Source: Eom and Ashill 2016, p.189)

\section{Dialogue}

The transactional distance in e-learning is defined as the psychological and communication space between the instructor and students (M. G. Moore, 1993). It can be reduced by many types of interactions: learner-content, learner-instructor, learner-learner, and learner-technology interaction (Hillman, Willis, \& Gunawardena, 1994; Michale G. Moore, 1989).

The constructivist model of learning views the interaction and dialogue between students and between the instructor and students as being critical ingredients to the success of e-learning. Several studies have conducted to incorporate only purposeful, constructive, meaningful interaction valued by each party (dialogue). Dialogue promotes learning through active participation and enables deep cognitive engagement for developing higher-order knowledge (M. G. Moore, 1993; Muirhead \& Juwah, 2004).

\section{Outputs}

Most of e-learning empirical studies have used perceived learning outcomes and perceived satisfaction as dependent constructs (Arbaugh, 2005; S. B. Eom, 2006, 2009, 2010; S. B. Eom, Ashill, \& Wen, 2006; LaPointe \& Gunawardena, 2004; Sun, Tsai, Finger, Chen, \& Yeh, 2008). An overarching consensus is that the dependent constructs in e-learning empirical studies include the learning outcomes and student satisfaction, based on the taxonomy of educational objectives in the domains of cognitive behaviors (Bloom, Engelhart, Furst, Hill, \& Krathwohl, 1956), affective behaviors (Krathwohl, Bloom, \& Masia, 1964), and psychomotor behaviors (Simpson, 1966). One important issue with e-learning empirical research is the measurement of learning outcomes. The majority of e-learning empirical studies that used actual learning outcomes such as grade point average, course grade have failed to establish the link between independent constructs and actual learning outcomes (Kellogg \& Smith, 2009). Thus, perceived learning outcomes are more frequently used constructs. 


\section{RESEARCH MODEL AND HYPOTHESES DEVELOPMENT}

The focus of current research is investigating the effects of student motivation and student selfregulation on e-learning outcomes and satisfaction (figure 2). Motivation is incentive that causes a person to act do a certain thing. According to Ryan and Deci (2000, p.. 56), intrinsic motivation is the psychological feature that makes an individual do an activity for its inherent satisfactions, for fun, or the challenge entailed, rather than for some separable consequence. Extrinsic motivation, on the other hand, makes an individual take an action toward a goal to attain some separable outcome such as rewards, recognition, etc.

Several attributes of students, as the primary participants of e-learning systems, have been major subjects of intense research over the past decade (S. B. Eom \& Arbaugh, 2011). Prior research findings identified a set of 31 determinants that have a significant effect on satisfaction and learning outcomes (Bitzer \& Janson, 2014). Of these, we focus on motivation and self-regulated learning strategies including metacognition, and learning engagement. Self-regulated learning is a pivotal learning strategy to achieve the intended e-learning outcome. Student motivation is a psychological construct that activates the selfregulation process (Barry J. Zimmerman, 2008).

\section{FIGURE 2 RESEARCH MODEL}

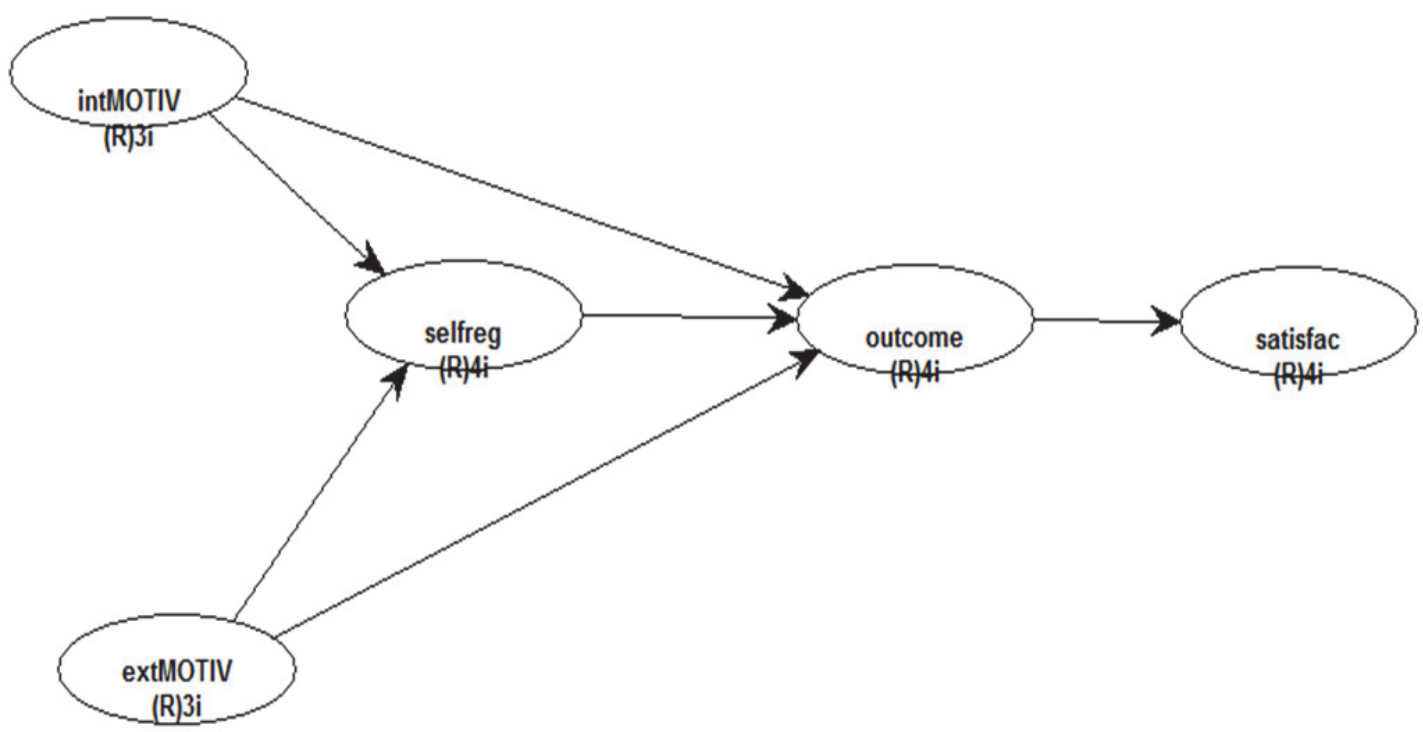

\section{Motivation and Learning Outcomes}

Continuing research on motivation has produced some empirical evidence indicating positive links between intrinsic motivation and satisfaction (S. B. Eom \& Ashill, 2016; S. B. Eom et al., 2006), between motivation and student performance (Castillo-Merino \& Serradell-López, 2014), social media engagement and motivational factors (Alt, 2015), and individual players' peer intrinsic and extrinsic motivation and intention to learn collaboratively and individually in a game-based learning environment (Kong, Kwok, \& Fang, 2012). Several recent empirical studies which concluded that motivation is the most important construct for explaining online students' ability to pass exams (Chua \& Don, 2013; Huet, Escribe, Dupeyrat, \& Sakdavong, 2011) and that motivation has a direct, positive and significant effect on students' achievement (Castillo-Merino \& Serradell-López, 2014). Therefore, we hypothesized: 
$\boldsymbol{H}_{1}:$ Students with a higher level of intrinsic motivation in online courses will report higher levels of agreement that the perceived learning outcomes are equal to or better than in face-to-face courses.

$\boldsymbol{H}_{2}$ : Students with a higher level of extrinsic motivation in online courses will report higher levels of agreement that the perceived learning outcomes are equal to or better than in face-to-face courses.

\section{Motivation and Self-regulated Learning Strategies}

Learning is a process of acquiring knowledge and skills. The learning process consists of planning, organizing, motivating, monitoring, evaluating, and controlling learning efforts and activities. According to Zimmerman (1989, p.329), self-regulated learners are "metacognitively, motivationally, and behaviorally active participants in their own learning process. Such students personally initiate and direct their own efforts to acquire knowledge and skill rather than relying on teachers, parents, or other agents of instruction."

Students' self-regulated learning has three essential features: Self-regulated students (1) select and use their self-regulated learning strategies to achieve desired learning outcomes, (2) continuously monitor the learning process and are responsive to self-oriented feedback about learning effectiveness, and (3) activate their interdependent motivational processes (Barry J. Zimmerman, 1990). A repertoire of learning strategies includes rehearsal, elaboration, organization, critical thinking, time/study environmental management, effort regulation, peer learning, help-seeking, and metacognitive self-regulation (P. R. Pintrich, Smith, Garcia, \& McKeachie, 1993).

In the e-learning area, students' metacognitive self-regulation and self-esteem in online courses were positively correlated with students' cognitive and emotional engagement (Pellas, 2014). Cognitive engagement refers to students' active participation and intellectual efforts to create/construct new knowledge in the learning process using cognitive and metacognitive strategies. The metacognitive strategies refer to a wide range of strategies used by learners to become aware of and in control of mental thought, including understanding their cognitive processes, learning their own learning styles, becoming aware of their own cognitive bias, and figuring out the most effective problem-solving strategies. Emotional engagement is concerned with high levels of students' interest and positive attitudes or values associated with the learning process.

Survey and interview findings (Kong et al., 2012) showed that an individual player's peer intrinsic and extrinsic motivations had significantly positive influence on his or her intention to learn collaboratively and individually when playing Massively Multiplayer Online Game. the relationship between theoretically grounded constructs of motivation and various metacognitive processes is examined (Moos, 2014) and it was found that extrinsic motivation significantly predicted the extent to which participants monitored their learning task goals with hypermedia. Therefore, we hypothesized:

\section{$\boldsymbol{H}_{3}:$ Intrinsic motivation will be positively related to the level of self-regulated learning.}

\section{$\boldsymbol{H}_{4}:$ Extrinsic motivation will be positively related to the level of self-regulated learning.}

\section{Self-regulated Learning Strategies and Learning Outcome}

A systematic review of past research from 2004 to 2014 examining self-regulated learning strategies and academic achievement in online higher education learning environments revealed that the strategies of time management, metacognition, effort regulation, and critical thinking were positively correlated with academic outcomes, but on the other hand rehearsal, elaboration, and organization had the least empirical support (Broadbent \& Poon, 2015). Moreover, students' use of the SRL strategies (metacognition, time management, and effort regulation) in a traditional face-to-face learning environment was strongly associated with a higher level of learning outcomes and it was a significant predictor of students' learning outcomes (Richardson, Abraham, \& Bond, 2012). Therefore, we hypothesized: 
$\boldsymbol{H}_{5}$ : A higher level of student self-regulation will lead to higher levels of student agreement that the learning outcomes of online courses are equal to or better than in face-to-face courses.

\section{Outcome and Satisfaction}

E-learners' learning outcomes and satisfaction have been two major dependent constructs in elearning empirical studies (S. B. Eom et al., 2006; Marks, Sibley, \& Arbaugh, 2005). In this study, learning outcomes are measured by the perceived level of students' quality of learning experience in online classes. Students' satisfaction is measured by their willingness to take online classes again or to recommend the instructor of online classes taken to other students. Thus, we hypothesized:

\section{$\boldsymbol{H}_{6}:$ Learning outcome will be positively related to e-learners'satisfaction.}

\section{SURVEY INSTRUMENT AND SAMPLE}

The survey questionnaire (see Appendix A) is selected from a previous study (S. B. Eom et al., 2006) which is in part adapted from the commonly administered IDEA (Individual Development \& Educational Assessment) student rating system developed by Kansas State University. In addition, the questionnaire on motivation and student self-regulation was adapted in part from the Motivated Strategies for Learning Questionnaire (MSLQ) (P. R. Pintrich et al., 1993), an 81-item, self-report instrument designed to measure college students' motivational orientations and their use of different learning strategies (Paul R. Pintrich, Smith, Garcia, \& McKeachie, 1991). We collected the e-mail addresses of 3285 students from the student data files achieved with every online course delivered through the online program of a university in the Midwestern United States. The 41 survey questions were created using SurveyMonkey(C). The survey URL and instructions were sent to 3285 e-mail addresses. We collected 382 valid unduplicated responses from the survey (11.63\% response rate). Of these responses, 10 incomplete responses with missing values were deleted.

\section{METHODOLOGY}

The research model (figure 2) is tested using WarpPLS, which is the structural equation modeling (SEM)-based Partial Least Squares (PLS) methodology. Model fit and quality indices were all acceptable levels.

\section{Measurement (Outer) Model Estimation}

The first step in data analysis involves model estimation. The test of the measurement model includes an estimation of the internal consistency and the convergent, discriminant, and factorial validity of the instrument items, as suggested by Straub et al. (2004). All reliability measures were above the recommended level of 0.70., thus indicating adequate internal consistency (Claes R. Fornell \& Bookstein, 1982; Nunnally \& Bernstein, 1994). The average variance extracted scores (AVE) were also above the minimum threshold of 0.5 (Chin, 1998; Claes R. Fornell \& Larcker, 1981) and ranged from 0.57 to 0.76. When AVE is greater than .50, the variance shared with a construct and its measures is greater than error. This level was achieved for all of the model constructs.

\section{Construct Validity}

Construct validity is assessed through establishing both convergent and discriminant validities. Convergent validity refers to the extent to which a set of indicator variables load together and they load highly (loading $>0.50$ ) on their associated factors. Individual reflective measures are considered to be reliable if they correlate more than 0.7 with the construct they intend to measure. Table 1 shows most of the loadings, except q34, were higher than the threshold value .7. When indicator variables do not crossload on two or more constructs, each construct is said to be demonstrating discriminant validity. In PLS, discriminant validity was assessed using two methods. First, by examining the cross-loadings of the 
constructs and the measures; Second, by comparing the square root of the average variance extracted (AVE) for each construct with the correlation between the construct and other constructs in the model (Chin, 1998; Claes R. Fornell \& Larcker, 1981). All constructs in the estimated model fulfilled the condition of discriminant validity (see Table 1).

\section{TABLE 1 MODEL VALIDATION RESULTS}

\begin{tabular}{ccccccc} 
& INTMOTI & EXTMOTI & SELFREG & OUTCOME & SATISFA \\
\cline { 2 - 3 } Q6 & 0.984 & -0.036 & 0.11 & 0.114 & -0.073 \\
Q7 & 0.986 & 0.033 & -0.101 & -0.105 & 0.067 \\
Q9 & 0.058 & 0.852 & 0.516 & -0.061 & -0.032 \\
Q10 & -0.018 & 0.97 & -0.208 & 0.116 & -0.048 \\
Q11 & -0.018 & 0.988 & -0.104 & -0.086 & 0.071 \\
Q30 & 0.035 & -0.062 & 0.989 & 0.126 & -0.039 \\
Q31 & -0.049 & 0.089 & 0.994 & 0.023 & -0.04 \\
Q32 & -0.115 & 0.084 & 0.984 & -0.094 & 0.042 \\
Q33 & 0.159 & -0.14 & 0.977 & -0.023 & 0.027 \\
Q34 & -0.013 & -0.058 & 0.065 & 0.673 & 0.734 \\
Q35 & -0.026 & 0.027 & 0.064 & 0.782 & 0.619 \\
Q36 & 0.01 & -0.003 & -0.022 & 0.936 & -0.351 \\
Q37 & 0.009 & 0.019 & -0.041 & 0.947 & -0.317 \\
Q38 & 0.022 & 0.013 & -0.129 & -0.204 & 0.97 \\
Q39 & -0.028 & -0.029 & 0.052 & -0.137 & 0.988 \\
Q40 & 0.026 & -0.001 & 0.208 & 0.519 & 0.828 \\
Q41 & -0.005 & 0.021 & -0.009 & 0.162 & 0.986 \\
\cline { 2 - 3 } Compo. RC & 0.844 & 0.795 & 0.841 & 0.93 & 0.923 \\
Cronbach's AC & 0.63 & 0.613 & 0.747 & 0.899 & 0.886 \\
AVE & 0.73 & 0.747 & 0.57 & 0.767 & 0.752 \\
\hline
\end{tabular}

Notes: Loadings and cross-loadings shown are after oblique rotation and Kaiser normalization. Composite RC: Composite Reliability Coefficients; Cronbach's AC: Cronbach's Alpha Coefficients; AVE: average variance extracted, \# All significant $\mathrm{p}<.05$.

\section{Reliability}

Reliability is concerned with the measurement accuracy within a construct while construct validity applies to the measurement between constructs. The composite reliability of a block of indicators measuring a construct was assessed with two measures - the composite reliability measure of internal consistency and average variance extracted (AVE). The internal consistency, Cronbach's alpha, is a measure of the extent to which a set of indicators of a latent construct are highly interrelated and therefore measure the same latent construct (Joseph F. Hair, Black, Babin, \& Anderson, 2010). All reliability measures were above the recommended level of 0.70 (Table 1), thus indicating adequate internal consistency (Claes R. Fornell \& Bookstein, 1982; Nunnally \& Bernstein, 1994). The average variance extracted scores (AVE) were also above the minimum threshold of 0.5 (Chin, 1998; Claes R. Fornell \& Larcker, 1981) and ranged from 0.72 to 0.913 (see Table 1). When AVE is greater than .50, the variance shared with a construct and its measures is greater than error. This level was achieved for all of the model constructs. Overall, the measurement model results provided support for the factorial, convergent, and discriminant validities and reliability of the measures used in the study. 


\section{Structural (Inner) Model Results}

Since PLS makes no distributional assumptions in its parameter estimation procedure, traditional parameter-based techniques for significance testing and model evaluation are considered to be inappropriate. Consistent with the distribution-free, predictive approach of PLS (Wold, 1985), the structural model was evaluated using the $R$-square for the dependent constructs, and the size, $t$-statistics, and significance level of the structural path coefficients. Table 2 shows the results of the warpPLS analysis, including the path coefficients. The results show that the structural model explains $71 \%$ of the variance in user satisfaction, and $64 \%$ of the variance in learning outcomes. The percentage of variance explained for these two primary dependent variables is greater than 10 percent, implying satisfactory and substantive value and predictive power of the PLS model (Falk \& Miller, 1992).

\section{R-Square for Dependent Constructs}

The results show that the structural model explains 15 percent of the variance in the learning outcome construct, and 64 percent of the variance in the user satisfaction construct. The percentage of variance explained for these primary dependent variables were greater than 10 percent implying satisfactory and substantive value and predictive power of the PLS model (Falk \& Miller, 1992).

\section{FIGURE 3 \\ STRUCTURAL MODEL RESULTS}

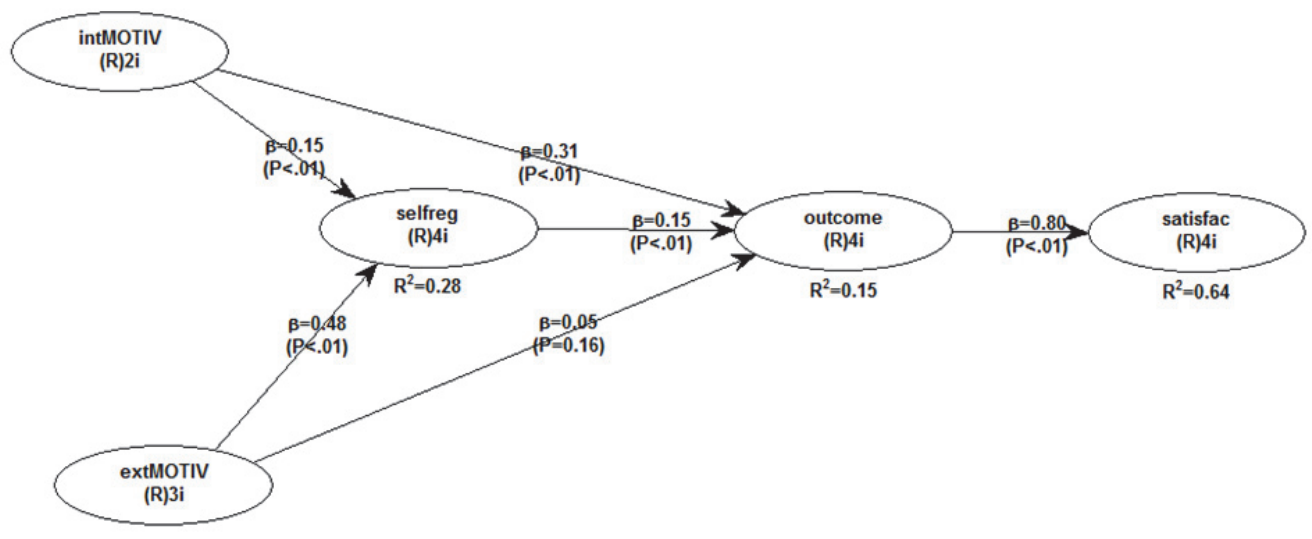


TABLE 2

STRUCTURAL (INNER) MODEL RESULTS

\begin{tabular}{|l|l|l|l|}
\hline & $\begin{array}{l}\text { Path } \\
\text { Coefficient }\end{array}$ & $P$ - value & $\begin{array}{l}\text { Hypothesis } \\
\text { support }\end{array}$ \\
\hline Effects on Learning Outcomes & $\mathrm{R}^{2}=0.15$ & & \\
\hline Intrinsic Student Motivation $\left(\mathrm{H}_{1}\right)$ & +0.31 & $<.01$ & Yes \\
\hline Extrinsic Student Motivation $\left(\mathrm{H}_{2}\right)$ & +0.05 & $=0.16 \mathrm{n} . \mathrm{s}$ & No \\
\hline Student Self-Regulation $\left(\mathrm{H}_{5}\right)$ & +0.15 & $<.01$ & Yes \\
\hline Effects on Self-Regulation & $\mathrm{R}^{2}=0.28$ & & \\
\hline Intrinsic Student Motivation $\left(\mathrm{H}_{3}\right)$ & +0.15 & $<.01$ & Yes \\
\hline Extrinsic Student Motivation $\left(\mathrm{H}_{4}\right)$ & +0.48 & $<.01$ & Yes \\
\hline Effects on Satisfaction & $\mathrm{R}^{2}=0.64$ & & \\
\hline Learning Outcome $\left(\mathrm{H}_{6}\right)$ & +0.8 & $<.01$ & Yes \\
\hline
\end{tabular}

n.s. not significant

\section{Structural Path Coefficients}

As can be seen from the results, of the three antecedent constructs hypothesized to affect learning outcomes, all of them are significant except extrinsic motivation, suggesting that intrinsic motivation directly affects learning outcomes and it activates learner's psychological learning process (self-regulated learning management). Intrinsic student motivation did have a significant positive association with learning outcomes. The results in Table 2 show a significant positive relationship between:

- Intrinsic motivation and self-regulated learning

- Self-regulated learning and learning outcome

- Extrinsic motivation and self-regulated learning

- Learning outcome and e-learner satisfaction

Only Hypothesis $\mathrm{H}_{4}$ was rejected. Extrinsic student motivation had no significant relationship with learning outcomes. The findings indicate that intrinsic student motivation $(\beta=.31)$ was the strongest predictor of learning outcome followed by self-regulation $(\beta=.15)$. Extrinsic student motivation had no significant and direct relationship with learning outcomes. Nevertheless, it was the strongest predictor of self-regulation.

\section{CONCLUSION AND DISCUSSION}

The main contributions of this study are twofold. First, in an earlier study, the motivation construct in the current study is further subdivided into intrinsic and extrinsic motivation. The findings indicate that intrinsic student motivation did have a significant positive association with learning outcomes. Extrinsic student motivation had no significant relationship with learning outcomes. The results of the current study on the effect of intrinsic motivation on learning outcomes are in accordance with the view of educational psychologists such as Zimmerman (Chua \& Don, 2013; Huet et al., 2011; 2003) and that motivation has a direct, positive and significant effect on students' achievement (Castillo-Merino \& Serradell-López, 2014). This study has significant implications for distance educators. Instructors teaching online classes 
should incorporate the inclusion of class assignment material that intellectually challenges e-learners so that the instructor stimulates students' intrinsic motivation.

Second, as the review of literature shows, there are few empirical studies that directly investigate the relationships among four constructs (intrinsic motivation, extrinsic motivation, self-regulation, and learning outcomes) in university online education. This study provided important empirical evidence in regard to the relationship between intrinsic motivation and self-regulatory learning strategies. The results of this study showed that both intrinsic motivation and extrinsic motivation activate the self-regulation process which in turn positively affect the learning outcomes.

\section{LIMITATIONS AND DIRECTIONS FOR FUTURE RESEARCH}

There exists a dynamic relationship among student motivation, instructor's facilitating roles, students' academic engagement, and learning management systems/information technology. Cho and Cho (2014) examined the relationship between instructor scaffolding for interaction and students' academic engagement in e-learning and concluded that online instructors' scaffolding for interaction had a significantly positive influence on students' behavioral engagement. The comprehensive picture of the roles of motivation and self-regulation can be identified with the inclusion of other constructs such as instructor, interaction, etc. Therefore, future research needs to further explore the identification of the antecedent of motivation, and the roles of motivation as a mediating variable affecting e-learning outcomes and satisfaction.

The current study's self-regulation construct included the strategies of metacognition, effort regulation, and organization. Future studies should focus on identifying the relationships between each of the self-regulatory learning strategies separately. As discussed in a prior section, prior studies show that students' use of each of the different SRL strategies has different effects on learning outcomes (Broadbent \& Poon, 2015; Richardson et al., 2012).

\section{REFERENCES}

Alt, D. (2015). College students' academic motivation, media engagement and fear of missing out. Computers in Human Behavior, 49, 111-119.

Arbaugh, J. B. (2005). Is there an optimal design for on-line mba courses? Academy of Management Learning \& Education, 4(2), 135-149.

Bitzer, P., \& Janson, A. (2014). Towards a holistic understanding of technology-mediated learning services - a state-of-the-art analysis. Paper presented at the European Conference on Information Systems (ECIS), Tel Aviv, Israel.

Bloom, B. S., Engelhart, M. D., Furst, E. J., Hill, W. H., \& Krathwohl, D. R. (1956). Taxonomy of educational objectives: The classification of educational goals. Handbook 1: Cognitive domain. New York: David McKay.

Broadbent, J., \& Poon, W. L. (2015). Self-regulated learning strategies \& academic achievement in online higher education learning environments: A systematic review. Internet and Higher Education, 27, $1-13$.

Castillo-Merino, D., \& Serradell-López, E. (2014). An analysis of the determinants of students' performance in e-learning. Computers in Human Behavior, 30, 476-484.

Chin, W. W. (1998). The partial least squares approach to structural equation modeling. In G. A. Marcoulides (Ed.), Modern methods for business research (pp. 295-336). Mahwah, NJ: Lawrence Erlbaum Associates.

Cho, M-H., \& Cho, Y. J. (2014). Instructor scaffolding for interaction and students' academic engagement in online learning: Mediating role of perceived online class goal structures. Internet and Higher Education, 21, 25-30.

Chua, Y. P., \& Don, Z. M. (2013). Effects of computer-based educational achievement test on test performance and test takers' motivation. Computers in Human Behavior, 29(5), 1889-1895. 
Dunn, R., Beaudry, J., \& Klavas, A. (1989). Survey research on learning styles. Education Leadership, 46, 50-58.

Eom, S. B. (2006). The role of the instructors as a determinant of students' satisfaction in university online education. The 6th IEEE International Conference on Advanced Learning Technologies (ICALT 2006), 985-988.

Eom, S. B. (2009). Effects of interaction on students' perceived learning satisfaction in university online education: An empirical investigation. International Journal of Global Management Studies, $1(2), 60-74$.

Eom, S. B. (2010). Relationship between e-learning systems and learning outcomes: A path analysis model Proceedings of 2010 10th international conference on advanced learning technologies (pp. 516-520). Sousse, Tunisia: IEEE Computer Society.

Eom, S. B. (2012). Effects of LMS, self-efficacy, and self-regulated learning on LMS effectiveness in business education. Journal of International Education in Business, 5(2), 129-144.

Eom, S. B. (2014). Understanding e-learners' satisfaction with learning management systems Bulletin of the IEEE Technical Committee on Learning Technology, 16(2/3), 10-13.

Eom, S. B. (2015). The effects of student motivation and self-regulated learning strategies on student's perceived e-learning outcomes and satisfaction. Association for Information Systems Special Interest Group for Education (AIS SIGED: IAIM) Conference, Paper No. 12. Retrieved from http://aisel.aisnet.org/siged2015/12

Eom, S. B. (2015). The effects of student motivation and self-regulated learning strategies on students' perceived e-learning outcomes and satisfaction. Association for Information Systems Special Interest Group for Education (AIS SIGED: IAIM) Conference.

Eom, S. B. (2017). A holistic model for understanding technology-mediated learning success. The 23rd Americas Conference on Information Systems (AMCIS).

Eom, S. (2019). The effects of mobile device usage on students' perceived level of dialog, self-regulated learning strategies and e-learning outcomes. 2019 IEEE 21st Conference on Business Informatics (CBI), 1, 329-334.

Eom, S. B., \& Arbaugh, J. B. (Eds.). (2011). Student satisfaction and learning outcomes in e-learning: An introduction to empirical research. Hersey, PA: Information Science Reference.

Eom, S. B., \& Ashill, N. (2016). The determinants of students' perceived learning outcomes and satisfaction in university online education: An update. Decision Sciences Journal of Innovative Education, 14(2), 185-215.

Eom, S. B., \& Ashill, N. (2018). A system's view of e-learning success model. Decision Sciences Journal of Innovative Education, 16(1), 42-76.

Eom, S. B., Ashill, N., \& Wen, H. J. (2006). The determinants of students' perceived learning outcome and satisfaction in university online education: An empirical investigation. Decision Sciences Journal of Innovative Education, 4(2), 215-236.

Eom, S. B., Ashill, N. J., Arbaugh, J. B. B., \& Stapleton, J. L. (2012). The role of information technology in e-learning systems success. Human Systems Management, 31(3), 147-163.

Falk, R. F., \& Miller, N. B. (1992). A primer for soft modeling. Akron, OH: The University of Akron Press.

Fornell, C. R., \& Bookstein, F. L. (1982). A comparative analysis of two structural equation models: Lisrel and pls applied to market data. In C. Fornell (Ed.), A second generation of multivariate analysis (pp. 289-394 ). New York: Praeger.

Fornell, C. R., \& Larcker, D. F. (1981). Evaluating structural equation models with unobservable variables and measurement error. Journal of Marketing Research, 18(1), 39-50.

Hillman, D. C. A., Willis, D. J., \& Gunawardena, C. N. (1994). Learner-interface interaction in distance education: An extension of contemporary models and strategies for practitioners. American Journal of Distance Education, 8(2), 30-42. 
Huet, N., Escribe, C., Dupeyrat, C., \& Sakdavong, J. C. (2011). The influence of achievement goals and perceptions of online help on its actual use in an interactive learning environment. Computers in Human Behavior, 27(1), 413-420.

Joseph F. Hair, J., Black, W. C., Babin, B. J., \& Anderson, R. E. (2010). Multivariate data analysis (7th ed.). Upper Saddle River, New Jersey: Prentice Hall.

Kellogg, D. L., \& Smith, M. A. (2009). Student-to-student interaction revisited: A case study of working adult business students in online course. Decision Sciences Journal of Innovative Education, 7(2), 433-454.

Kong, J. S-L., Kwok, R. C.-W., \& Fang, Y. (2012). The effects of peer intrinsic and extrinsic motivation on mmog game-based collaborative learning. Information \& Management, 49(1), 1-9.

Krathwohl, D. R., Bloom, B. S., \& Masia, B. B. (1964). Taxonomy of educational objectives: The classification of educational goals. Handbook ii: Affective domain. New York, NY: David McKay Co., Inc.

LaPointe, D. K., \& Gunawardena, C. N. (2004). Developing, testing and refining of a model to understand the relationship between peer interaction and learning outcomes in computer-mediated conferencing. Distance Education, 25(1), 83-106.

Marks, R. B., Sibley, S., \& Arbaugh, J. B. (2005). A structural equation model of predictors for effective online learning Journal of Management Education, 29(4), 531-563.

Moore, M. G. (1989). Three types of interaction. The American Journal of Distance Education, 3(2), 1-6.

Moore, M. G. (1993). Theory of transactional distance. In D. Keegan (Ed.), Theoretical principles of distance education (pp. 22-38). New York, NY: Routledge.

Moos, D. C. (2014). Setting the stage for the metacognition during hypermedia learning: What motivation constructs matter? Computers \& Education, 70, 128-137.

Muirhead, B., \& Juwah, C. (2004). Interactivity in computer-mediated college and university education: A recent review of the literature. Educational Technology \& Society, 7(1), 12-20.

Nunnally, J. C., \& Bernstein, I. H. (1994). Psychometric theory (3rd ed.). New York: McGraw-Hill.

Pellas, N. (2014). The influence of computer self-efficacy, metacognitive self-regulation and self-esteem on student engagement in online learning programs: Evidence from the virtual world of second life. Computers in Human Behavior, 35, 157-170.

Piccoli, G., Ahmad, R., \& Ives, B. (2001). Web-based virtual learning environments: A research framework and a preliminary assessment of effectiveness in basic it skills training. MIS Quarterly, 25(4), 401-426.

Pintrich, P. R., Smith, D. A. F., Garcia, T., \& McKeachie, W. J. (1991). A manual for the use of the motivated strategies for learning questionnaire (mslq). Ann Arbor: University of Michigan: National Center for Research to Improve Postsecondary Teaching and Learning.

Pintrich, P. R., Smith, D. A. F., Garcia, T., \& McKeachie, W. J. (1993). Reliability and predictive validity of the motivated strategies for learning questionanaire (mslq). Educational and Psychological Measurements, 53, 801-813.

Richardson, M., Abraham, C., \& Bond, R. (2012). Psychological correlates of university students' academic performance. A systematic review and meta-analysis Psychological Bulletin, 138, 353387.

Ryan, R. M., \& Deci, E. L. (2000). Intrinsic and extrinsic motivations: Classic definitions and new directions. Contemporary Educational Psychology, 25(1), 54-67.

Simpson, E. (1966). The classification of educational objectives, psychomotor domain. Retrieved from Washington, D.C.

Straub, D., Boudreau, M-C., \& Gefen, D. (2004). Validation guidelines for is positivist research. Communications of the Association for Information Systems, 13(24), 380-427.

Sun, P.-C., Tsai, R. J., Finger, G., Chen, Y.-Y., \& Yeh, D. (2008). What drives a successful e-learning? An empirical investigation of the critical factors influencing learner satisfaction. Computers \& Education, 50(4), 1183-1202. 
Wold, H. (1985). Systems analysis by partial least squares. In P. Nijkamp, H. Leitner, \& N. Wrigley (Eds.), Measuring the unmeasurable (pp. 221-252). Dordrecht: Martinus Nijhoff.

Zimmerman, B. J. (1986). Development of self-regulated learning: Which are the key subprocesses? . Contemporary Educational Psychology, 16, 307-313.

Zimmerman, B. J. (1989). A social cognitive view of self-regulated academic learning. Journal of Educational Psychology, 81(3), 329-339.

Zimmerman, B. J. (1990). Self-regulated learning and academic achievement: An overview. Educational Psychologist, 25(1), 3-17.

Zimmerman, B. J. (2008). Investigating self-regulation and motivation: Historical background, methodological developement, and future prospects. American Educational Research Journal, 45(1), 166-183.

Zimmerman, B. J., \& Campillo, M. (2003). Motivating self-regulated problem solvers. In J. E. Davidson \& R. J. Sternberg (Eds.), The nature of problem solving (pp. 233-262). New York: Cambridge University Press. 


\section{APPENDIX: SURVEY QUESTIONS}

\section{Student Intrinsic Motivation}

6. In an online class like this, I prefer class material that really challenges me so I can learn new things.

7. When I have the opportunity in this online class to choose class assignments, I choose the assignments that I can learn from even if they don't guarantee a good grade.

8. I do all that I can do to make my assignments turn out perfectly.

\section{Student Extrinsic Motivation}

9. I work hard to get a good grade even when I don't like a class.

10. I want to do well in this online class because it is important to show my ability to my family, parents, or others.

11. I like to be one of the most recognized students in a class

\section{Self-regulation}

30. In the beginning, I set my goals and plan accordingly according to what I need to do to make desired learning outcomes.

31. Even when study materials are dull and uninteresting, I keep working until I finish.

32. I keep up with my grades in each course, and if one seems to be sliding, I'll stress that class more in my studying.

33. When I study for a test, I try to put together the information from class notes and from the book.

\section{Learning Outcomes}

34. The academic quality of this online class is on par with face-to-face classes I've taken.

35. I have learned as much from this online class as I might have from a face-to-ace version of the course.

36. I learn more in online classes than in face-to-face classes.

37. The quality of the learning experience in online classes is better than in face-to-face classes.

\section{User Satisfaction}

38. I would recommend this instructor to other students.

39. I would recommend this online class to other students.

40. I would take an online class at this university again in the future.

41. I was very satisfied with this online class. 